\title{
Palm Dates, Power, and Politics in Pre-Oil Kuwait
}

\author{
Eran Segal
}

1

\section{Introduction*}

Palm dates have been a major source of subsistence and important spiritual symbols in the Arabian Peninsula since ancient times. However, much of the research done so far has mainly focused on the Gulf pearls and their transit trade due to their especially attractive nature, while less exotic commodities, such as dates, have received less critical attention, despite their essential role in the life of local populations. This chapter attempts to fill in this gap by addressing the importance of dates for the material culture of the Arabian Peninsula, and the economic and political impact they had in this area from the eighteenth century onwards. As I argue here, in pre-oil times date ownership played an essential role in the regional balance of power and shaped in significant ways the relationship between Kuwaiti rulers and merchants, on the one hand, and Kuwaiti and Iraqi rulers and the British protectorate, on the other. This case study will demonstrate the confluence of dates' material powers ${ }^{1}$ with capital accumulation and politics in the process of state formation in Kuwait.

Since the foundation of modern Kuwait in the eighteenth century, it has been ruled by the same family. This is not an uncommon occurrence in the Gulf; however, due to existing internal conflicts and foreign influences, a unique power balance was

* This chapter is an updated version of the article "Rulers and Merchants in Pre-Oil Kuwait: The Significance of Palm Dates," (c) 2014 British Society for Middle Eastern Studies, reprinted by permission of Taylor \& Francis on behalf of the British Society for Middle Eastern Studies.

1 I use here this notion in the sense given to it by Patrick Joyce and Tony Bennett, i.e., "recognizing distinctive forms of agency and effectivity on the part of material forces" (4). See "Material Powers: Introduction," in Material Powers: Cultural Studies, History and the Material Turn, ed. Patrick Joyce and Tony Bennet (Abingdon: Routledge, 2010), 1-22. created in Kuwait, one that is yet to be systematicallystudied. The main power in the Kuwaiti society remained in the hands of two main groups: rulers (the Sabah family) and merchants. It has often been claimed that the relations between these groups have changed dramatically due to the discovery of oil ${ }^{2}$ but, as this chapter will demonstrate, this change predated oil and happened in an evolutionary rather than revolutionary way. The economic impact of palm dates and the ownership of date gardens are some of the main causes of this change.

The date gardens mentioned here were situated in the Shat al-Arab (southern Iraq) and mainly in the Fao Peninsula. Kuwaitis controlled these gardens for more than a hundred and twenty years and this had a considerable impact on their politics and society. Although historians did write about the role of dates and date gardens in Kuwait, this was done mainly on the sidelines of their narrative. Therefore, this chapter will, first, elaborate on the importance of dates and the need for studying their influence. Then, it will address the role of palm dates in the Kuwaiti history in general and in the Sabah family in particular. Finally, it will discuss the palm dates in relation to Kuwaiti merchants and the impact they had on Kuwaiti society. This impact has a broader relevance in the Arabian Peninsula given the common history of the local populations until a relatively recent past.

\section{The Importance of Palm Dates}

Palm dates (Phoenix dactylifera) have been a dietary staple in human civilization. There is evidence of their existence since 6,00o B.c. and of

\footnotetext{
2 See, for example, Jill Crystal, Oil and Politics in the Gulf: Rulers and Merchants in Kuwait and Qatar (Cambridge: Cambridge University Press, 1995).
} 
their domestication since around 4,000 B.C., which make dates one of the first fruits ever cultivated. ${ }^{3}$ There are different theories about their origin, but the domestication of dates probably started in Mesopotamia and in the Shat al-Arab area itself. ${ }^{4}$

There are hundreds of different varieties of dates. In Iraq, more than six hundred varieties are known but most of them are rare. The most common are Barhi, Halawi, Khadrawi, Sair, Zahidi, Dairi, Buraim, and Maktum. ${ }^{5}$ Date palms can reach a height of up to eight meters. They need to be nurtured for seven years until they first bear fruit but, following that, within a few years, a single palm will produce between 80 to 120 kilograms of fruit per year. Palms are also resilient to difficult weather conditions, including fires, which do not affect the core of the tree. ${ }^{6}$ Nevertheless, flooding can cause irreversible damage as it happened, for example, in the Shat al-Arab area in 1896 and 1935, when flooding caused the destruction of over one million palm trees each time. ${ }^{7}$

Growing palms requires a combination of relatively high temperatures, especially during the ripening process, and large amounts of water. ${ }^{8}$ This

3 Daniel Zohari, Maria Hopf, and Ehud Weiss, Domestication of Plants in the Old World: The Origins and Spread of Domesticated Plants in the Southwest Asia, Europe, and the Mediterranean Basin (Oxford: Oxford University Press, 2012), 131.

4 Mark Beech, "Archaeobotanical Evidence for Early Date Consumption in the Arabian Gulf," in The Date Palm: From Traditional Resource to Green Wealth (Abu Dhabi: The Emirates Center for Strategic Studies and Research, 2003), 11-31.

5 V.H.W. Dowson, Dates \& Date Cultivation of the Iraq (Cambridge: W. Heffer \& Sons, 1921-1923), 3 and 23-81. Different sources give different spellings to some varieties.

6 For details, see Abdelouahhab Zaid, ed., Date Palm Cultivation (Rome: Food and Agricultural Organization of the United Nations, 2002).

7 Reidar Visser, Basra, the Failed Gulf State: Separatism and Nationalism in Southern Iraq (Münster: LIT Verlag, 2005), 15 .

8 The average minimum temperature for palm trees to survive and grow is between 13 and $27^{\circ} \mathrm{C}$; at the time of pollination, they require a temperature between 21 and $27^{\circ} \mathrm{C}$. makes Shat al-Arab an exceptionally favorable natural area for growing them. The peak of the ripening process is from September to November. In the past, this timing suited the transit trade, which could bring the fruit to India during the winter and thus finance the purchase of goods brought back to the Arabian Gulf.

The date growing process requires relatively large amounts of manual labor ${ }^{9}$ and it needs yearround work in order to yield substantive crops. It demands skilled manpower, but it can also provide work for women and children, who are the ones packing the dates. The management of the gardens was generally under the control of field agents, who had complex relations of profit sharing with the fallahs (farmers). According to Hala Fattah, in the nineteenth century the trade was based on partnership contracts and long-term credit in future transactions. In return for securing the yield, the merchants paid six or seven months in advance, usually through a middle man (dalla $l)$ rather than through direct contact with the cultivators. ${ }^{10}$

It is interesting to note that in the pre-oil era the dates were packed in special cases called khisf or khasaf, and that the boats built in the Gulf area were categorized according to the number of date cases they could carry, no matter whether the boat was made for dates, pearls, or other transit trade products. Not only the fruit but also the palm tree

Cf. ChihCheng T. Chao and Robert R. Krueger, "The Date Palm (Phoenix dactilifera L.): Overview of Biology, Uses, and Cultivation," HortScience 42, no. 5 (2007): 1077-082.

Fuad Ishaq Khuri, Tribe and State in Bahrain: The Transformation of Social and Political Authority in an Arab State (Chicago: University of Chicago Press, 1980), 39-40.

10 Hala Fattah, The Politics of Regional Trade in Iraq, Arabia, and the Gulf, 1745-19oo (New York: SUNY Press, 1997), 85-88. Jabir al-Mubarak, Hakim [Ruler of] alKuwait, to Marzuk bin Muhammad al-Marzuk (15 Dhu al-Hijja, 1334 [1916]), in Kuwait Political Agency: Arabic Documents 1899-1949, ed. Alan de Lacy Rush (Buckinghamshire: Archive Editions, 1994), 4:40-41. 
and its leaves were used by the local populations. The palm trunk was the main source of wood for house furniture, crates, or boats. The leaves were used for ropes, baskets, and rugs, and the date stones were used for feeding the cattle. ${ }^{11}$

Dates have four ripening stages generally known by their Arabic names as kimri, khalal or basr, ru$t a b$, and tamr. Kimri describes the unripe fruit while khalal describes the fresh dates, picked and sold at an early stage of ripeness. In the third stage, the fruit is the ripest, but it lasts the shortest. In the last stage, the fruit is dried and is at its best for the longest time. This quality of the date made it a staple food for nomads, especially during harsh, long travels. It also allowed the dates to be exported to the Far East by sea since tamr could last for a couple of months. ${ }^{12}$ But what made the date a major staple food was the fact that it provided all the elements of a basic diet. The fruit contains carbohydrates and most of the vitamins and minerals needed to humans. ${ }^{13}$ Moreover, it can be easily used for making a variety of products like sugar, syrup, wine, spreads, beverage, and cakes. As a result, the material culture of food in the Arabian Peninsula has been historically centered on dates, which were called the "bread of the desert": together with the camel milk, dates were the main source of subsistence for the Bedouin tribes. ${ }^{14}$

Dates were not only commodities with an important economic value but also essential elements to the Arabian Peninsula material culture. Dates used to be religious symbols and were used in traditional medicine. ${ }^{15}$ They appeared in most

11 Yusuf al-Shihab, Rijal fi Ta'arikh al-Kuwait [Men in the history of Kuwait] (Kuwait: n.p., 1993), part 2, 298.

12 Frauke Heard-Bey, From Trucial States to United Arab Emirates (London: Longman, 1982), 176-77. It should be mentioned that cooking the dates prolongs their durability for many months.

Zvi Berenstein, Hatamar [The palm date] (Tel-Aviv: Tirush, 2004), 237-39.

14 Nawal Nasrallah, Dates: A Global History (London: Reaktion Books, 2011), 9.

15 Loutfi Boulos, Medicinal Plants of North Africa (Algonac: Reference Pubns, 1983), 140. of the cultures of the ancient world and in all the monotheistic religions. The date is mentioned nineteen times in the Qurān, either as a symbol for God's generosity or as a warning against uprooting palms. Both these contexts emphasize its spiritual and economic importance for the people in the area. ${ }^{16}$ Moreover, dates appear in many traditions related to the holy month of Ramadan. Breaking the fast is traditionally made with dates and milk, and a special non-alcoholic champagne made from dates is reserved for the night celebrations. In Oman, a large boiled dates industry has developed over time: dates are exported from here to India for wedding ceremonies. ${ }^{17}$ Describing the date culture in Al-Hasa (North-East Arabia), American anthropologist F.S. Vidal has emphasized the large vocabulary which evolved around this industry, which indicates its importance and high degree of specialization, and compared the attitude of the local populations toward dates to the attitude of nomadic tribes toward camels. ${ }^{18}$

Dates were also used in important ceremonies like the tahnik, which involves rubbing a boy's palate with dates after his birth as a way of curbing his natural desires and as a symbol of his acceptance within the community. ${ }^{19}$ In traditional medicine,

16 The date also appears in the Hadith and it is always a positive symbol. See F. Viré, "Nakhl," in Encyclopaedia of Islam, ed. Jean-Christophe Pellat and Jay Heinrichs (Leiden: Brill, 1993), 7:923-24; and David Waines, "Date Palm," in Encyclopaedia of the Qur'ān, ed. Jane Dammen (Leiden: Brill, 2001), 1:494-95 W.J. Donaldson, "A Note on the Tarkabah and the Omani Boiled Date Trade," in New Arabian Studies 2, ed. R.L. Bidwell, G. Rex Smith, and J.R. Smart (Exeter: University of Exeter Press, 1994), 68-74. For late twentieth century social functions of the dates in Oman, see Mandana E. Limbert, "The Sacred Date: Gifts of God in an Omani Town," Ethnos 73, no. 3 (2008): 361-76. F.S. Vidal, "Date Culture in the Oasis of Al-Hasa," The Middle East Journal 8, no. 4 (1954): 417-28.

19 Avner Giladi, "Some Notes on Tahnik in Medieval Islam," Journal of Near Eastern Studies 47, no. 3 (1988): 175-79; Avner Giladi, "Saghir," in Encyclopaedia of Islam, ed. Clifford Edmund Bosworth (Leiden: Brill, 1995), 8:824. 
dates were used for disinfection, for making a syrup against colds, and for sobering up. The Yemeni used palm vinegar (khall) for digestive problems, and Arab sailors staved off the dangers of scurvy by eating dates during their long voyages of trade. $^{20}$

Palm dates have been an important source of trade in the Arabian Gulf, which was the main area for their growing since ancient times. ${ }^{21}$ According to Paul Popenoe, in 1926 there were 90 million palms in the world. Over half of these were grown in the Gulf area; out of these, 30 million were found in Iraq and about 15 million in the Shat alArab area. ${ }^{22}$ During the 1930s, Basra exported 85 percent of the world date supply, mainly to the West and India. ${ }^{23}$ During his tour of the Gulf between 1916-1917, C.M. Curstejee wrote about date that "it has been and is unmistakably the main source of the sustenance of the poor and the wealth of the rich of this country."24 In 1924, Albert C. Wratislaw, the former British consul at Basra between 1898-1903, estimated that 9o percent of

20 Martin Vanhove, "The Making of Palm Vinegar at AlHiswah (near Aden) and Some Other Crafts Related to Palm Trees," in Bidwell, Smith, and Smart, New Arabian Studies 2, 175-85.

Rosemary Said Zahlan, The Making of the Modern Gulf States: Kuwait, Bahrain, Qatar, the United Arab Emirates and Oman (London: Unwin Hyman, 1989), 1.

Paul Popenoe, "The Distribution of the Date Palm," Geographical Review 16, no. 1 (1926): 117; Visser, Basra, 13-17. According to Visser, the date trade is the main explanation for the rise of Basra in the second half of the nineteenth century.

23 Cecil Byford, The Port of Basrah, Iraq (Basra: Waterlow \& Sons Ltd., 1935), 127-28.

24 C.M. Cursetjee, The Land of the Date: A Recent Voyage from Bombay to Basra and Back, Fully Descriptive of the Ports and Peoples of the Persian Gulf and the Shat'el-Arab, Their Conditions, History, and Customs: 1916 1917 (Reading: Garnet, 1996), 130. Dates were also the main (and almost only) export of Muhammarah; for details, see Shahbaz Shahnavaz, Britain and the Opening Up of South-West Persia, 1880-1914: A Study in Imperialism and Economic Dependence (London: RoutledgeCurzon, 2005), 108-09.
Basra's population lived on the date industry. ${ }^{25}$ Therefore, the dates played a complex social, cultural, and economic role in the Arabian Peninsula, in general, and in the history of Kuwait, in particular, shaping the power relationship between the local merchants and the rulers. As Arjun Appadurai aptly explains, rulers and merchants are closely linked by their rivalry over the social regulation of demand. While merchants look for new tastes and commodities, the political elites strive for restricted exchanges and fixed commodity systems. ${ }^{26}$

\section{The Sabah Ruling Family and Palm Dates}

In order to understand the impact that palm dates have had on Kuwait's history, I will provide, first, a brief explanation of its involvement in the date production in Iraq. During 1918-1920, V.H.W. Dowson conducted a unique and thorough survey of the dates in southern Iraq. He estimated that the Shat al-Arab area was home to about 15 million palms and evaluated them at $£ 2,500,000$. According to his findings, date exports represented 60 to 70 percent of Iraq's total exports. In an article published in 1939, he estimated that there were only 6 million date bearing palms left in Shat al-Arab, and they produced about 130,000 tons of dates per year. About 100,000 tons of these dates and another 50,000 tons of dates from other parts of Iraq were exported from the port of Basra for a total value of about $£ 1,000,000$ a year. ${ }^{27}$

The date gardens in this area under Kuwaitis' possession were assessed by the British at 7,742 jarīb (a little more than $30,000,000$ square meters,

25 Albert C. Wratislaw, A Consul in the East (Edinburgh: William Blackwood and Sons, 1924), 160.

26 Arjun Appadurai, "Introduction: Commodities and the Politics of Value," in The Social Life of Things: Commodities in Cultural Perspective (Cambridge: Cambridge University Press, 1986), 33.

27 Dowson, Dates \& Date Cultivation of the Iraq, 17; V.H.W. Dowson, "The Date Cultivation and Date Cultivators of Basrah," Journal of the Royal Central Asian Society 26, no. 2 (1939): 247. 
or 3,00o hectares). ${ }^{28}$ The main area, Fao, was 6,056 jarīb (more than 24,000 hectares) and contained over 300,000 palms. ${ }^{29}$ The other areas cultivated with dates were Faddaghiya, Bashiya, Mutaw'a, Ajirawiya, and Farhaniya. ${ }^{30}$ Estimates regarding the value of these assets are difficult to make due to lack of sufficient information. In the British records, different figures appear, which makes it clear that the value of the assets was fluctuating during that time. Throughout the 1930s, general estimates revolved around $£ 1,000,000 .{ }^{31}$ Existing records of date exports indicate that, at the beginning of the twentieth century, the Kuwaiti rulers' revenue came predominantly from the sale of dates. In the 1930s, the ruler Ahmad al-Jabir claimed that the date gardens were his family's main source of income and, although this statement came as part of a struggle over the date gardens, it was probably correct. ${ }^{32}$

I will start with an analysis of the main changes occurred in the period under discussion. There are three main stages in the history of palm dates and the Sabah family. The first stage describes the beginning of the family's control over the gardens; the second one is the Mubarak era (18961915), when the gardens assumed a major role in the Kuwaiti-Iraqi-British relationship; and the third one describes the final battle over the gardens, which eventually changed the socio-political

28 A jarīb is 3,967 square meters.

29 India Office Records R/15/5/136, F.H. Humphrys, High Commissioner for Iraq to Lord Passfield, Secretary of State for the Colonies (29 May 1931), The British Library, London (henceforth IOR). Relying on Fattah's estimation that each jarīb contained 100 trees, this will add to a double figure. See Fattah, Politics of Regional Trade, 86.

They appear only in the British Archives.

31 In 1958, A.S. Halford, the British Agent in Kuwait (19571959), estimated that the lands were worth $£_{3}, 000,000$, but this was probably an exaggeration. For details, see Foreign Office $371 / 132839$, A.S. Halford to Foreign Office, London (30 June 1958), The National Archives, London (henceforth FO).

IOR R/15/5/135, Political Agent, Kuwait to Political Resident, Bushire (14 September 1930). balance in Kuwait. Naturally, there are other explanations for some of the historical events described here and they did not occur exclusively as a consequence of the trade in dates. Nevertheless, palm dates played a crucial role in the power dynamics of the region.

\subsection{The Nineteenth Century: The Acquiring Stage}

It is difficult to determine when the first date gardens were purchased or taken by force by the $\mathrm{Ku}$ waitis. It is likely that the merchants were the first to acquire them, and that the Sabah family followed. ${ }^{33}$ The beginning of the Sabahs' ownership of the gardens dates back to the 183os, during the first years after the end of the Mamluks' rule over Iraq, a period characterized by political instability. The town of Zubair showed unacceptable autonomy and the Ottomans asked Jabir, the Kuwaiti ruler, to lay siege to the town. Yaqub al-Zuhair, head of one of the leading families in Zubair, escaped to Kuwait, where he was placed under Jabir's protection. According to a source, Yaqub then sold his date gardens in the Fao Peninsula to Jabir for 12,000 Shami. According to another source, al-Zuhair gave the land to Jabir in gratitude for saving his life. Later, a dispute arose as to whether the land was actually sold to the Sabah family or was given to Jabir only for the period of his life. ${ }^{34}$ No matter

33 There were no arable lands in Kuwait, as opposed to Bahrain, for instance, so rulers and merchants went outside Kuwait for properties. It should be mentioned that in Bahrain the Shi'is were the main cultivators while the Sunnis, including the al-Khalifa ruling family, were landowners. See Khuri, Tribe and State in Bahrein, 37-53.

"Précis of Koweit Affairs," in The Persian Gulf Précis. Volume v: Nejd Affairs-Koweit Affairs-Turkish Expansion ... and Hasa and Katif Affairs, ed. J.A. Saldanha (Buckinghamshire: Archive Editions, 1986), 4; J.G. Lorimer, Gazetteer of the Persian Gulf, Oman, and Central Arabia (Calcutta: Superintendent Government Printing, 1915), 1008; Alan Rush, Al-Sabah: History \& Genealogy of Kuwait's Ruling Family 1752-1987 (London: Ithaca Press, 1987), 175 and 241-44; Abdullah al-Khatim, Min Huna Bada't al-Kuwait [From here Kuwait started] 
which story is true, this move marks the beginning of the Sabah family's economic autonomy. Following this acquisition, evidence shows that the family accumulated substantial wealth from the date gardens.

During the Jabir period (1814-1859), the Kuwaitis were successful in exploiting the weaknesses of the Ottomans and later the Iraqis, which allowed them to control the date gardens for an extensive period of time. A significant event in the region at the end of the nineteenth century was that Midhat Pasha, Wãli (governor) of Baghdad (1869-1872), occupied the Al-Hasa region. After Faisal's death in 1865 , Midhat entered the battle of succession in Najd to obtain a hold on Arabia. Because he lacked naval force, it is likely that Midhat would not have succeeded in his attempt, but Abdullah al-Sabah, the Kuwaiti ruler, provided him with ships and supplies for his campaign. As a result, for the first time in the Kuwaiti history, Midhat conferred the title of Qaimaqām (Ottoman governor of a district) on Abdullah. ${ }^{35}$ Nevertheless, it is highly unlikely that Abdullah would have risked a move against the Saudis, who controlled Al-Hasa, just for gaining an Ottoman title. For the previous one hundred and twenty years, the Sabah rulers had never tried to obtain the title, which was not important to them. This gesture should be understood, therefore, as Abdullah's need to address Midhat's enforcement of the Land Law (1858) in Iraq. Midhat had initiated a land settlement policy and conducted surveys in Iraq following which he ordered tapu (land registration) certificates and established tax rates. ${ }^{36}$ When the Kuwaitis took control over the date gardens in Iraq, no structured

(Damascus: Al-Matba'ah al-'Umumiyya, 1963), 53-57. Shami was a silver currency used by tribesmen until the early twentieth century. See Fattah, Politics of Regional Trade, 223. Salwa Alghanim, The Reign of Mubarak Al-Sabah: Shaikh of Kuwait 1896-1915 (London: I.B. Tauris, 1998), 13-14; Rush, Al-Sabah, 140.

36 Hana Batatu, The Old Social Classes and the Revolutionary Movements of Iraq (Princeton, NJ: Princeton University Press, 1978), 53-55, 74, and 240 . registration process was in place, so they were not able to provide proof of their land ownership.

It is likely, then, that Abdullah was concerned about Midhat attacking him and losing his family's lands. Midhat curtailed the movement of dates in 1871, which indicated to Abdullah that he could inflict further damage. ${ }^{37}$ This had a significant impact on the Sabah family's fortune and enabled them to solidify their economic power. It seems, however, that this fortune caused a rift within the family over how to manage it, which led to a unique period in the Kuwaiti history.

\subsection{The Mubarak Era (1896-1915): Consolidating Control}

Mubarak al-Sabah was the only ruler in the Kuwaiti history to take the rule by force, after killing his brother, Muhammad, in 1896. There are several stories about his motives, and they all emphasize his greed and ambition to rule. There are no direct links in historical records between the date gardens and his murderous act ${ }^{38}$ except for one line in a British source. In the annual Administration Report of 1896, Kuwait is mentioned for the first time in a line explaining that Mubarak murdered his brothers because he "had failed to get their recognition of his claims on the joint family property." ${ }^{39}$ No explanations or details are

Frederick F. Anscombe, The Ottoman Gulf: The Creation of Kuwait, Saudi Arabia, and Qatar (New York: Columbia University Press, 1997), 21-22; Rush, Al-Sabah, 140. See also John Barrett Kelly, Britain and the Persian Gulf, 1795-1880 (Oxford: Clarendon Press, 1968), 717-35.

In a 1896 report of the legal adviser to the British Embassy in Constantinople, the date gardens were described as the reason for the rulers accepting the Ottoman rank of Qaimaqām. See "Memorandum by Mr. Stavrides," in Ruling Families of Arabia: Kuwait, ed. A. Rush de Lacy (Buckinghamshire: Archive Editions, 1991), 14-15.

"Administration Report on the Persian Gulf Political Residence for the Year 1896-7," in The Persian Gulf Administration Reports, 1873-1947 (Buckinghamshire: Archive Editions, 1986), 8-9. Abdullah Williamson, who was in Kuwait at the time, also claimed that one of the reasons for Mubarak's acts was his brother, who was depriving him of any share in the date revenues. See 
given, but other clues in the records clarify these circumstances.

According to Rush, Mubarak's dissatisfaction with his brothers was fueled by his mother, Lu'lu'a al-Thaqib. ${ }^{40}$ The Thaqib family owned many date gardens in the region and it was the greatest rival of al-Zuhair in Zubair. Lu'lu'a married Sabah, Jabir's son, after Jabir helped her father. Although the records do not contain any other information, it is likely that she was the one who urged Mubarak to take possession of these profitable lands. Indeed, throughout Mubarak's era, the date gardens were central to his economic policies.

One of the major steps taken by Mubarak was to sign an agreement with the British in January 1899. The British had already entered into agreements with Bahrain and other rulers from the Gulf area. Mubarak accepted their terms but demanded from M.J. Mead, the British Political Resident in the Persian Gulf between 1897-1900, to add a letter to the agreement whereby the British agreed to give their "good offices" to Mubarak. ${ }^{41}$ Mead was aware of the possible consequences of such a commitment but he was compelled by Mubarak to sign the agreement following Mubarak's disclosure of his contacts with the Russians, French, and Germans, who were also interested in reaching an agreement with him. At the time, the British were determined to block an Ottoman-German plan to build the Baghdad railway, which was supposed to end in Kuwait. Mead also reported that Mubarak's brothers declined to sign an agreement because of the lack of commitment of the British "to protect Koweit family $[s i c]$ in their estates near Fao." ${ }^{42} \mathrm{He}$

\footnotetext{
also Stanton Hope, Arabian Adventurer: The Story of Haji Williamson (London: Robert Hale, 1951), 132.

Kelly claimed that Mead told Mubarak the "good offices" included the protection of his estates in Fao, but there is no written record of this agreement. See John B. Kelly, "Salisbury, Curzon and the Kuwait Agreement of 1899," in Studies in International History: Essays Presented to W. Norton Medlicott, ed. K. Bourne and D.C. Watt (London: Longmans, 1967), 281.

42 Robin Bidwell, ed., The Affairs of Kuwait, 1896-1905 (London: Frank Cass, 1971), 39-40.
}

reported Mubarak's explanation that those properties were part of Kuwait and had been gradually conquered by the Ottomans. This was the first time that the British had heard about the date gardens and, not surprisingly, the first time they used their "good offices" when Mubarak demanded their help with his properties on the Fao Peninsula in April 1899. ${ }^{43}$ This explains the place of the dates in the agreement. Nearly every year of his rule, Mubarak filed complaints to the British about the Ottoman activities against him. At that time, Mubarak was buying more date gardens in Fao and applying for loans from the British, seemingly due to a shortage of money. ${ }^{44}$

Lorimer estimated that, at the beginning of the twentieth century, Mubarak's annual revenue was 399,000 Thalers (Maria Theresa Dollars), or $£ 80,000.45$ The revenues from the date gardens were 108,00o Thalers, which was about 27 percent of his total income. The rest of his taxes, which were considerably higher than those of his predecessors, including the taxes on pearls, did not come even close to his revenues from dates. ${ }^{46}$ In 1913, he declared that he could pay back the loan he had taken from the British, which was about 600,000 Rupees $(£ 60,000)$, after the money from the sale of dates arrived. ${ }^{47}$ Although he probably exaggerated, it is obvious that the dates were his principal sources of revenue and, more importantly, that his income was not dependent on his

Political Resident to Sheikh Mubarak (21 April 1899), in Rush, Kuwait Political Agency, 1:180-81. Probably only then did the British understand the complexity of the problem and its consequences on their relations with the Ottomans. The agreement was supposed to be secret in order not to harm the stability of the Ottomans. Bidwell, The Affairs of Kuwait, 64-66; see, also, the note by L.W. Reynolds, Offg. Deputy Secy. to the Government of India (1 June 1909), in Records of Kuwait, 18991961, ed. Alan de Lacy Rush (Buckinghamshire: Archive Editions, 1989), 1:733.

45 At the time, a Thaler was about two Rupees. See Anscombe, Ottoman Gulf, xiii-xiv.

46 Lorimer, Gazetteer of the Persian Gulf, 1076.

47 IOR L/P\&S/10/48, Political Agent, Kuwait to Political Resident, Bushire (11 November 1913). 
merchants' economic success. There are no similar estimations of the Kuwaiti rulers' revenues on record. However, it is more than likely that the share of dates grew gradually throughout the first half of the twentieth century.

At the start of World War I, the British were keen on ensuring Mubarak's support. On November 3 , 1914, only days before invading the Basra area, the British gave Mubarak a letter with three commitments in return for his siding with them. The first commitment read: "your gardens, which are now in your possession, viz., the date gardens situate between Fao and Qurnah, shall remain in your possession and in possession of your descendants without being subject to the payment of revenue or taxes." ${ }^{48}$ This commitment turned into a major problem in the Kuwaiti-Iraqi-British relationship at the end of World War I, until the final settlement of this issue in the 1950s.

\subsection{Ahmad al-Jabir Era (1921-1950): The Fruits of the Struggle}

In the 1920 and 1930s, the world saw a gradual economic decline; for Kuwait, this period was extremely difficult. The decline in the transit trade and the demise of the pearl trade after the introduction of cultured pearls brought many Kuwaitis to starvation. In this context, the revenues from the date gardens became even more important. The fact that the Sabah family and the ruler, Ahmad al-Jabir, continued to enjoy the profits of the dates was critical in strengthening their political position.

Due to the commitment made by Britain to $\mathrm{Ku}-$ wait, the date gardens became a problem for the former. Starting with 1922, the Iraqi government continually complained that they were not part of the British commitment and that the agreement was an assault on their sovereignty and lowered their revenues. The Iraqis began pushing for a decision in their favor by publishing numerous

48 Political Resident in the Persian Gulf to Mubarak asSubah (3 November 1914), in Rush, Kuwait Political Agency, 1:210-12. newspaper articles that emphasized their enormous loss of tax money. ${ }^{49}$

Ahmad al-Jabir, on the other hand, did everything he could to keep the date gardens and to strengthen his hold on them. He used the fact that the British officials were frequently changed to his advantage and he told different things to different agents. Most of the time, he claimed that the lands were his but in 1930, after the British advised him to sell the gardens in order to improve his strained relationship with Iraq, he informed them that the land belonged to all his family members and any selling "might easily cause revolution in Kuwait." ${ }^{50}$ Ahmad knew, of course, that this was one of the things the British were afraid of. It did not take them long to realize that Ahmad had fooled them and he had been managing all the date gardens without any involvement of his family. ${ }^{51}$ Ahmad did not need the support of his family as the merchants had become weaker; however, he did change his attitude toward his family members and started relying on them to preserve his power.

The British-Iraqi negotiations in 1930 were not successful on the date gardens issue, but it was clear that, as Iraq approached independence in 1932, some arrangement had to be made. ${ }^{52}$ Starting with 1930, probably as a result of the encouragement from the Iraqi government, a series of private lawsuits were filed by members of the $\mathrm{Zu}$ hair family and others, claiming small parts of the Sabah date gardens. These lawsuits were followed

49 See, for example, IOR R/15/5/135, "Press Extracts, ALIraq No. 2320 of 17 August 1927. Exemption of the Shaikhs of Kuwait and Mohammerah from Miri Fees. When Is This Prejudice to Iraq's Right to Disappear?"

5o IOR R $/ 15 / 5 / 135$, Political Resident, Bushire to Secretary of State for the Colonies, London (31 August 1930).

51 IOR R/15/5/136, Political Agent, Kuwait to Political Resident, Bushire (1 January 1931).

52 The details in this section are mainly based on the "Summary of Negotiations over as Subah Date Gardens, 1914-1952," found in Rush, Records of Kuwait, 6:207-26, and H.V.F. Winstone and Zahra Freeth, Kuwait: Prospect and Reality (London: George Allen \& Unwin, 1972), 111-18. 
by many appeals by all sides which created legal complications that lasted many years. Moreover, the new Iraqi state began to issue new rules and regulations that, at least in Kuwaitis' eyes, were meant to diminish their profits. ${ }^{53}$

In 1933, Faisal, the Iraqi king, declared that the lands would stay under the Kuwaiti ruler's management, but his death prevented the conclusion of a settlement. Under king Ghazi's rule, the IraqKuwait struggle escalated, and the date gardens became an obstacle to any possible appeasement. In the 1940s, it became obvious to the British that the Sabah family could not hold the date gardens for long, so they concentrated their efforts on a joint agreement and settlement of the different aspects of the issue. In 1947, Rupert Hay, the British Resident in the Persian Gulf (1946-1953), had already decided to offer the Kuwaiti ruler a sum of $£ 400,000$, half of the value (as the British estimated) of all date gardens, in order to end the problem, but this decision was eventually dropped and no compensation was offered.

During the rule of Abdullah al-Salim (19501965), the date gardens period came to an end. It seems that, even though the date gardens were no longer important economically to Kuwaitis due to the oil money, keeping them was a question of honor. So, Abdullah refused to compromise, and the British representatives recommended not to offer any compensation to avoid offending him in the eyes of his family. ${ }^{54}$ More importantly, because he was striving to achieve the Kuwaiti independence, Abdullah detached himself from the British and sought Arab recognition instead. ${ }^{55}$

After money became abundant in the 1950s, Abdullah was less keen on confronting Iraqi

53 IOR $R / 15 / 5 / 136$, "Note on a Conversation Which the Hon'ble the Political Resident in the Persian Gulf Had with the Shaikh of Kuwait" (25 October 1931). Foreign Office 371/82042, Political Agent, Kuwait to Political Resident in the Persian Gulf (2 May 1950). Simon C. Smith, Kuwait, 1950-1965: Britain, the Al-Sabah, and Oil (Oxford: Oxford University Press, 1999), 46-48. lawyers and the Iraqi government, ${ }^{56}$ but the revolution of July 1958, which resulted in an overthrow of the Iraqi monarchy, completely changed the political landscape again. In August 1958, the British reported that the Iraqi authorities had used every means to stop the fallahs from taking the Sabah family's lands, ${ }^{57}$ but it was probably the other way around. In December 1958, Abdullah met Abd alKarim Qasim, the Iraqi ruler, and although he had promised to agree on a solution, Abdullah told the British he was not satisfied with any. ${ }^{58}$ Interestingly, on June 1959 it was the fallahs of Fao who petitioned Qasim to find a solution, and a few months later, Abdullah informed the British that he was about to approach the Iraqis for a settlement. ${ }^{59}$ This was only to inform the British, though, and, not surprisingly, it is the last mention of this question in the British archives. The British lost their influence as Iraq withdrew from the Baghdad Pact, and the agrarian reform of September 1958 further complicated the Sabah family's ability to control the lands. Further information regarding the arrangement that put an end to this epoch is still to be found.

\section{$4 \quad$ Merchants and Palm Dates}

Besides the Sabah family, merchants were the most influential elite in pre-oil Kuwait. This elite (also known as tujjär) was mainly engaged in the import and export trade. In many urban centers of the Middle East and in the small societies of the Gulf, the merchant elite stood at the top of the

56 Political Agent, Kuwait to the Eastern Department, Foreign Office (26 June 1958), in Rush, Records of Kuwait, 6:236-37.

57 Telegram from Consul General, Basra to Foreign Office (21 August 1958), in Rush, Records of Kuwait, 6:239-40.

$5^{8}$ FO 371/132594, Political Agent, Kuwait to British Ambassador, Iraq (16 December 1958).

59 FO 371/140221, British Consul, Basra to Political Agent Kuwait (23 June 1959), Political Agent, Kuwait to Political Resident in the Persian Gulf (5 October 1959). 
commercial communities. This elite did not include all merchants but only those with large enterprises, profits, and liquid assets. This enabled them to operate vast commercial networks, make significant investments, and attain political power. The state formation following World War I reduced the power of the merchants who, following the economic crisis of the late 1920s, found themselves in a different position in relation to Kuwaiti rulers, who maintained their control of the palm dates.

It cannot be determined exactly when the Kuwaitis began to invest in date gardens, but it is known that that the ones who started the process were the merchants. In the eighteenth century, Kuwaiti rulers relied for their income mainly on taxes, which were relatively low, so their income was modest. On the other hand, the merchants' revenues increased quickly, especially after the two conquests of Basra by the Iranians (1776-1779 and 1793-1795), which transferred British economic activities from there to the Kuwaiti ports. Possibilities to invest money in Kuwait were rather limited, so the merchants gradually started to invest outside Kuwait in order to secure their wealth.

Existing evidence shows that the merchant alSaqir purchased land in the year 1245 to the hijra (1829/30), just before the Sabah family did. ${ }^{60}$ Indirect evidence also shows that merchants had purchased date gardens before Sabah. In 1908, a deed of sale from 8 Sha'ban 1233 to the hijra (1818) was brought before S.G. Knox, the British Political Agent in Kuwait (1904-1909). This was provided by Saqir al-Ghanim, the son of one of the wealthiest and most important families in Kuwait, who owned date gardens in Bahrain. The circumstances of this transaction are not clear. ${ }^{61}$ Owning lands in that period did not generally require written proof as the land was passed from generation to

6o Yusuf Bin Muhammad al-Nisf, Nahlatak [Your date gardens] (Kuwait: n.p., 1998), 39.

61 IOR R/15/5/21, Political Agent, Kuwait to Political Agent, Bahrain (28 December 1908). generation within families. The merchant families maintained economic relations with local farmers with minimal outside interference. Another indication of the ways in which merchants started owning lands is the story of Abd al-Jalil al-Tabtaba'i. He owned large date gardens in the Basra area and immigrated with his family from Zubair to $\mathrm{Ku}-$ wait in $1842 .{ }^{62}$ We can assume that al-Tabtaba'i was not the only one who did so and that other merchants immigrated to Kuwait "with their lands" in the same way.

There is considerably more information about the merchants who dealt with palm dates in the twentieth century. Probably the leading merchant was Hamad al-Saqir, who initiated and stood as head of the first Majlis (council) formed in Kuwait in 1921. He was known as Malik al-Tummūr (the King of Palm dates), as he was a major exporter of dates and owned several date gardens in the area. ${ }^{63}$ Interestingly, Hilal al-Mutairi, who was the wealthiest merchant in Kuwait due to the trade in pearls, also bought date gardens in the late 1920 as he moved away from pearls just before their trade crashed. In 1929, existing reports mention his visits to the many date gardens he owned in the Shat al-Arab area. ${ }^{64}$

Unfortunately, there is almost no information about the level of merchant ownership of the date gardens. In 1936, Gerald de Gaury, the political agent in Kuwait (1936-1939), assumed that about thirty-five Kuwaiti families had date gardens in Iraq, but he did not mention where this figure

62 Adnan bin Salim bin Muhammad al-Rumi, Ulema alKuwait w-A'alamiha hilal Thalathat Qurun [Scholars and famous people of Kuwait in the past three centuries] (Kuwait: Maktabat al-Manar al-Islamiyya, 1999), 37-53.

63 Hamad Muhammad al-Sa'idan, Al-Musu'a al-Kuwaitiyya al-Muhtasira [Brief Kuwaiti encyclopedia] (Kuwait: AlMatba'a al-'Asriyya, 1970-1972), 875 .

64 IOR R/15/5/181, Political Agent, Kuwait to Administrative Inspector, Basrah (9 November 1929). 
came from or on what he based his information. ${ }^{65}$ A British document, probably from the 1930s, claimed that " $[\mathrm{r}]$ ich Kuwaitis find the soundest investment for their surplus money in land, and preferably the date gardens of lower Iraq. Many had and have gardens there; the Shaikhs of Kuwait among their number." 66 There is almost no other information about their ownership, except by indirect means. ${ }^{67}$

Therefore, it is reasonable to assume that, as the Iraqis took control of the region, the Kuwaiti merchants' opportunities to invest in dates decreased. There are also indications that some lands, one way or another, came into the hands of the Sabah family. In 1911, Qasim al-Ibrahim, a big Kuwaiti merchant who resided in Bombay, purchased a vast date garden in Shat al-Arab for 180,00o Turkish Lira (1,620,00o Rupees, or £162,000). In 1935, when rumors spread about the possibility of finding oil there, he first approached Ahmad al-Jabir, the Kuwaiti ruler, and then the British officials, claiming that these were his lands, not the Sabahs', and that he was entitled to the profits from them. ${ }^{68}$ This case may indicate that the Sabah family took over the Kuwaiti merchants' lands, but it can also be an outcome of the many lawsuits started in the 1930 and the confusion created by them.

65 Political Agent, Kuwait to British Consul, Bushire (12 March 1936), in Rush, Records of Kuwait, 6:425. IOR R/15/5/157, "Introductory Note by Political Agent to the Case of the Heirs of Zuhair Versus the Mail Heirs of Shaikh Mubarak and their Descendants." n.p.

67 For example, in an interview, Badir Khalid al-Badir alQina'i described his childhood in the 1920s and his visits to his father's date gardens, which were located between the date gardens of the Humaidhi family and those of the Ghanim family. See Yusuf al-Shihab, Rijal fi Ta'arikh al-Kuwait [Men in the history of Kuwait] (Kuwait: Matabi' Dar al-Qabas, 1993-200o), 3 and 38, respectively.

Rush, Records of Kuwait, 1:342. Translation of the letter received from Sheikh Jasim bin Mohamed Ebrahim, Bombay, in Rush, Records of Kuwait, 2:100-01; the letter was probably written in November 1935. Al-Nisf described his family as the biggest owner of date gardens in Kuwait. For details, see Al-Nisf, Nahlatak, 35.
Merchants are mainly mentioned in sources as traders in dates involved in exporting them from the Shat al-Arab to India and East Africa. As Ahmad al-Jabir claimed in the 1930s, most of the export from this area was done by Kuwaiti merchants using agents of the Sabah family. ${ }^{69}$ In the 1930 , the involvement of the merchants in the date trade grew considerably as the pearl trade and the transit trade sharply declined. It is interesting to note that five of the fourteen members of the second Majlis (1938) were engaged in the date trade, compared to only one, al-Saqir, in the first Majlis. This increase is a clear indication of the rising importance of palm dates during that period. However, the merchants could not manage the date trade as freely as they did in the nineteenth century and obviously lacked the political power of the Sabah family.

\section{Conclusion}

Palm dates have been a dietary staple in human civilization, especially in the Arabian Peninsula. Throughout history, they have been an important source of subsistence and played an essential role in the cultural traditions of the region. Moreover, the dates had an important impact on the economy and socio-political life of pre-oil Arabia. By being aware of the economic strength that the trade in dates brought to the Sabah ruling family of Kuwait, one can better understand their resulting political power at the beginning of the twentieth century. Since the pre-oil Kuwaiti society was based on a merchant elite and collecting high taxes from them was not possible, the ruling family's resources were quite limited. Therefore, over a long period of time, the Sabah family gradually purchased and took control of extensive date

69 "Proofs of Nature of Tasarruf Maintained in Ruler's Fau Property" (n.d.), in Rush, Kuwait Political Agency, 7:534-36. IOR $\mathrm{R} / 15 / 5 / 136$, "Note on a Conversation Which the Hon'ble the Political Resident in the Persian Gulf Had with the Shaikh of Kuwait" (25 October 1931). 
plantations in southern Iraq, and thus built up its economic power base in parallel with the creation of a political power base.

The date gardens period lasted for a hundred and twenty years and deserves special attention in the Kuwaiti pre-oil history. The importance of this period is clearly shown by the uncompromising struggle of Ahmad al-Jabir to keep the date gardens they owned in Iraq in the hands of the Sabah family. Although more than once this struggle against Iraq jeopardized al-Jabir's relations with the British, which were critical for Kuwait and the Sabah family's survival, it shows how far the ruling family was ready to go in order to maintain its economic power. The economic importance of the dates in the power dynamics of the area is also reflected by the ruling family's competition with $\mathrm{Ku}$ waiti merchants over the ownership of date gardens in the nineteenth century and beyond. Thus, this case study indicates the essential role played by material powers in the state formation in $\mathrm{Ku}$ wait: as a source of economic wealth, the dates translated in political power for the ruling family and shaped in complex ways its relations with the British protectorate. Further studies on the trade in dates in the Arabian Peninsula may unveil more about their effect on processes of state formation in the region. 